Бурак Валентина Геннадіївна кандидат технічних наук, доцент, доцент кафедри готельно-ресторанного та туристичного бізнесу, Херсонський державний університет, вул. Університетська, 27, м. Херсон, 73003, тел.: (050) 982-83-32, e-mail: burak_valia@ukr.net, https://orcid.org/0000-0001-5097-6536

\title{
ПРОЄКТНІ ТЕХНОЛОГІЇ В ПРОФЕСІЙНІЙ ПІДГОТОВЦІ МАЙБУТНІХ ФАХІВЦІВ ГОТЕЛЬНО-РЕСТОРАННОЇ СПРАВИ
}

Анотація. У статті проаналізовано структурно-системне вивчення досвіду використання проєктних технологій під час професійної підготовки майбутніх фахівців готельно-ресторанної справи у закладах вищої освіти. Установлено, що професійна підготовка майбутніх фахівців готельно-ресторанної справи $\epsilon$ організованим, безперервним і цілеспрямованим процесом формування і розвитку в здобувачів освіти необхідних для фахової діяльності професійних компетентностей, який здійснюється в закладах вищої освіти різних форм власності та спрямовується на здобуття майбутніми фахівцями кваліфікацій відповідно до освітньо-професійних програм освітніх рівнів «бакалавр» і «магістр» спеціальності 241 Готельно-ресторанна справа, що забезпечить успішне виконання посадових обов'язків, конкурентоспроможність і професійну мобільність у сфері послуг, а також своєчасне оновлення та вдосконалення.

Здійснений аналіз диференціації підходів до визначення дефініцій поняття «проєктні технології» в дослідженнях науковців дає підстави стверджувати про їхню розлогість та різновекторність. Завдяки аналізу наукових досліджень розглянуто основні вимоги до організації проєктної технології, іiі принципи, головні етапи і практичні дії, проаналізовано класифікацію проєктів на види. Установлено організаційно-педагогічні умови розроблення проектних технологій, до яких віднесено цілеспрямовану мотивацію до проектного професійного навчання; створення сприятливого для проектного професійного навчання інноваційного освітнього середовища; формування готовності педагогів та здобувачів освіти до проєктної діяльності; підготовку навчально-методичних матеріалів і дидактичних комплексів для проєктного професійного навчання

На основі практичного досвіду провадження навчально-пізнавальної діяльності в умовах дистанційного навчання, власного та викладачів кафедри готельно-ресторанного та туристичного бізнесу Херсонського державного університету, здійснено аналітико-синтетичні дослідження особливостей організації вищеозначеного освітнього процесу засобами використання проєктних технологій.

Ключові слова: майбутні фахівці, готельно-ресторанна справа, професійна підготовка, заклади вищої освіти, проєктні технології. 
Burak Valentyna Gennadyevna Candidate of Technical Sciences, Associate Professor, Associate Professor at the Department of hotel-restaurant and tourist business, Kherson State University, University St., 27, Kherson, 73003, tel.: (050)-982-83-32, e-mail: burak_valia@ukr.net, https://orcid.org/0000-0001-5097-6536

\title{
PROJECT TECHNOLOGIES IN PROFESSIONAL TRAINING OF FUTURE SPECIALISTS IN HOTEL AND RESTAURANT BUSINESS
}

\begin{abstract}
The article analyzes structural and systematic study of the experience of using project technologies during the training of future specialists in hotel and restaurant business in higher educational establishments. It is established that professional training of future specialists in hotel and restaurant business is an organized, continuous and purposeful process of formation and development of professional competencies necessary for professional activity, which is carried out in higher education institutions of various forms of ownership and is aimed at obtaining qualifications by future specialists according to educational and professional programs of educational levels «bachelor» and «master», specialty 241 Hotel and restaurant business, which will ensure successful performance of official duties, competitiveness and professional mobility in the field of services, as well as timely updating and improvement.

The analysis of the differentiation of approaches to the definition of the concept «design technologies» in scientific research gives grounds to assert their diversity. Due to the analysis of scientific researches the basic requirements to the organization of project technology, its principles, main stages and practical actions are considered, classification of projects on kinds is analyzed. Organizational and pedagogical conditions for the development of project technologies have been established, which include purposeful motivation for project professional training; creation of an innovative educational environment favorable for project professional training; formation of teachers'and students' readiness for project activities; preparation of educational and methodical materials and didactic complexes for project professional training.

Based on the practical experience of conducting educational and cognitive activities in distance learning, own and teachers of the Department of Hotel, Restaurant and Tourism Business of Kherson State University, analytical and synthetic studies of organization of the above educational process through the use of project technologies was carried out.
\end{abstract}

Keywords: future specialists, hotel and restaurant business, professional training, higher educational establishment, project technologies.

Постановка проблеми. Сутність якісної підготовки фахівця, стратегічні напрями формування його особистості в процесі професійної освіти сформульовані в нормативних документах, зокрема Національній доктрині розвитку освіти України у XXI столітті, закладені в законодавчих документах Міністерства освіти і науки України: Законах України «Про освіту», «Про вищу освіту», «Про фахову передвищу освіту», «Про професійну (професійнотехнічну) освіту», Концепції реалізації державної політики у сфері професійної 
(професійно-технічної) освіти «Сучасна професійна (професійно-технічна) освіта» на період до 2027 року тощо. Сучасні дослідження науковців підтверджують необхідність такої якості освіти, яка дозволить випускникам закладів освіти вільно входити в реальне життя та брати активну участь у здійсненні перебудови української економіки й суспільства.

Аналіз останніх досліджень і публікацій. Професійна підготовка майбутніх фахівців - це складний динамічний організаційно-педагогічний процес, складна багаторівнева педагогічна система, багатогранний феномен розвитку професійності, період завершення професійного самовизначення особистості. Визначальним при цьому вважаємо таке розуміння означеної дефініції: цілеспрямований процес організаційно-педагогічної взаємодії зі здобуття фахових знань, формування умінь, навичок, компетентностей та готовності до майбутньої діяльності в обраній галузі знань за ознаками певної сукупності професійних завдань та обов'язків (робіт), які виконує фахівець; розвиток світоглядних засад майбутньої професії та значущих особистісних якостей, набуття первинного спеціального досвіду.

Якісна підготовка майбутніх фахівців за умов постійної модернізації означеного процесу вимагає використання інноваційних інтерактивних технологій, серед яких значне місце займає проєктна. Проєктні технології підготовки студентів стали об'єктом зацікавлення дослідниці Т. Сілакової [1]. Науковці Н. Науменко та А. Козлов вивчали можливості проєктної технології навчання у професійній підготовці майбутніх фахівців [2]; проектні технології в процесі професійно-педагогічної підготовки майбутніх фахівців закладів вищої освіти - О. Колодницька [3]; проєктні технології для професійної підготовки майбутніх кваліфікованих робітників аграрної, будівельної та автотранспортної галузей досліджували Н. Кулалаєва та Г. Романова [4].

Проєктні технології у процесі професійної підготовки майбутніх кухарівкондитерів аналізувала М. Мелько [5], проектну методику навчання професійного спілкування в процесі вивчення іноземних мов майбутніми фахівцями готельноресторанної справи - Т. Поночовна-Рисак та І. Величко [6], підготовку майбутніх магістрів з туризмознавства до проектної професійної діяльності - А. Тимейчук [7].

Науковець О. Протас досліджувала проєктні технології у процесі підготовки майбутніх соціальних педагогів до роботи з обдарованими дітьми [8], Т. Розумна - активізацію пізнавальної діяльності студентів засобами проєктної технології на заняттях з іноземної мови у ВНЗ (ЗВО - авт.) [9], С. Соболєва - проектні технології та їх роль у процесі практично-професійної підготовки студентів економічних спеціальностей [10]. Науковцями також деталізовано теорію і практику проєктного навчання у професійно-технічних навчальних закладах (закладах освіти - авт.) [11] тощо.

Мета статті - структурно-системне вивчення досвіду використання проєктних технологій під час професійної підготовки майбутніх фахівців готельно-ресторанної справи у закладах вищої освіти.

Виклад основного матеріалу. Для реалізації мети розкриємо понятійнокатегоріальний апарат. У контексті нашого дослідження вагомим $є$ трактування 
деталізованого визначення «професійна підготовка майбутніх фахівців готельно-ресторанного господарства», під якою розумітимемо організований, безперервний i цілеспрямований процес формування i розвитку в здобувачів освіти необхідних для фахової діяльності професійних компетентностей, який здійснюється в закладах вищої освіти різних форм власності та спрямовується на здобуття майбутніми фахівцями кваліфікацій відповідно до освітньо-професійних програм освітніх рівнів «бакалавр» i «магістр» спеціальності 241 Готельноресторанна справа, що забезпечить успішне виконання посадових обов'язків, конкурентоспроможність і професійну мобільність у сфері послуг, а також своєчасне оновлення та вдосконалення [12, с. 9].

Під поняттям «технологї̈» у науково-педагогічній літературі розуміють змістовну техніку та способи оптимального втілення мети навчальнопізнавальної діяльності через доцільне використання методів, за умови дотримання послідовності спільних дій учасників освітнього процесу та подальшої педагогічної діагностики з метою отримання відповідного результату. Значущим у цьому процесі $\epsilon$ врахування технічних, людських ресурсів та можливостей взаємодії задля забезпечення повної керованості ним.

До традиційних технологій провадження освітнього процесу відносять навчальні: предметно та особистісно орієнтовані, кредитно-трансферну, інтерактивні, сервісні, концентрованого і розвивального навчання, проєктні, навчання як дослідження, педагогічних майстерень, колективної розумової діяльності, евристичного навчання, персоніфікованого навчання; освітні: особистісної та життєтворчої орієнтації освітнього процесу, активізації та інтенсифікації діяльності студентів, ефективності управління та організації освітнього процесу, здоров'язбережувальні освітні технології та запобігання й подолання конфліктів, організації самостійної та самоосвітньої роботи студентів тощо.

Нинішні реалії здійснення освітнього процесу з використанням технологій дистанційного навчання активізують самостійну роботу 3 матеріалами навчальних дисциплін на електронних платформах закладів вищої освіти i провайдерів неформальних освітніх послуг. До технологій дистанційного навчання належать універсальні й спеціалізовані інформаційні системи (інформаційно-комунікаційні (цифрові), інформаційно-пошукові, інформаційноаналітичні), технології зовнішнього стандартизованого тестування, мультимедійні, ігрові, розвивального, проєктного, змішаного, диференційованого, програмованого, модульного навчання, спеціалізовані програмні продукти, котрі застосовуються в діяльності суб’єктів готельного та ресторанного бізнесу тощо).

Тож проєктна як одна 3 інноваційних освітніх технологій забезпечує формування основних компетентностей здобувачів освіти, повну узгодженість навчання із їхній життям та інтересами, активний розвиток мислення в інтеграції 3 наукою.

Вивчення досвіду використання проєктних технологій під час професійної підготовки майбутніх фахівців, заакцентоване в дослідженнях українських 
науковців, уможливило укладання таблиці 1. Диференціація підходів до визначення дефініцій поняття «проєктні технології» в дослідженнях науковців.

\section{Диференціація підходів до визначення дефініцій поняття «просктні технології» в дослідженнях науковців}

Таблицуя 1

\begin{tabular}{|c|c|}
\hline $\begin{array}{c}\text { Автори- } \\
\text { дослідники }\end{array}$ & Тлумачення поняття «проектна технологія» \\
\hline $\begin{array}{l}\text { О. Колодницька } \\
{[3, \text { с. } 87]}\end{array}$ & $\begin{array}{l}\text { проєктна технологія є сукупністю різноманітних методів, форм і засобів, } \\
\text { спрямованих на розвиток творчої особистості майбутнього фахівця, які дають } \\
\text { можливість у наочній формі поетапно моделювати предметну область, } \\
\text { аналізувати цю модель на всіх етапах їі розробки. Вона вказує на конкретні } \\
\text { способи, засоби й результати здійснення творчої, професійної діяльності, } \\
\text { стимулює інтерес студентів до вирішення актуальної проблеми з практичним } \\
\text { застосуванням отриманих результатів }\end{array}$ \\
\hline $\begin{array}{l}\text { Н. Кулалаєва, } \\
\text { Г.Романова } \\
{[4, \text { с. } 3]}\end{array}$ & $\begin{array}{l}\text { проєктна технологія професійного навчання - упорядкована і систематизована } \\
\text { продуктивна пошукова діяльність учнів ЗП(ПТ)О під керівництвом педагогів, у } \\
\text { процесі якої вони індивідуально, в парах або в підгрупах проектують і } \\
\text { виконують пізнавальні та практичні завдання, в результаті чого отримується } \\
\text { конкретний творчий продукт. }\end{array}$ \\
\hline $\begin{array}{l}\text { Н. Наум } \\
\text { А. Козл } \\
{[2, \text { с. } 15}\end{array}$ & $\begin{array}{l}\text { проєктування - це особливий тип інтелектуальної діяльності, відмінною } \\
\text { особливістю якої є перспективна орієнтація, практично спрямоване } \\
\text { дослідження...передбачає включення механізмів запам'ятовування й } \\
\text { відтворення інформації; передачу інформації іншим; застосування знань у } \\
\text { варіативних ситуаціях; розуміння причинно-наслідкових зв'язків, } \\
\text { співвідношення частин і цілог; наведення аргументів та доказів, } \\
\text { перегрупування окремих частин і створення нового цілого тощо }\end{array}$ \\
\hline О. Про & $\begin{array}{l}\text { сутність проєктної технологї полягає в ефективній роботі комплексу } \\
\text { дидактичних засобів (змісту, методів, прийомів), під час якої навчально-виховна } \\
\text { діяльність узгоджується зі структурними та організаційними вимогами } \\
\text { навчального проєктування. Використання проєктних технологій спрямоване на } \\
\text { інтеграцію різних навчальних дисциплін у процесі професійної підготовки } \\
\text { студентів, реалізацію взаємозв'язку теорії і практики, підвищення посилення } \\
\text { ролі самоосвіти, саморозвитку студентів, формування у них компетенцій і } \\
\text { професійно важливих якостей }\end{array}$ \\
\hline $\begin{array}{l}\text { T. Розумна } \\
{[9, \text { с. 277] }}\end{array}$ & $\begin{array}{l}\text { проєктна технологія спрямована на сформовані раніше професіональні } \\
\text { компетентності студентів, на розвиток особистості студентів, їхніх творчих } \\
\text { здібностей, самостійність у виконанні проекту. При цьому проектна технологія } \\
\text { поєднує в собі всі види навчально-пізнавальної роботи: індивідуальної, парної, } \\
\text { групової, колективної }\end{array}$ \\
\hline Т. Сілакова [1] & $\begin{array}{l}\text { проєктна технологія передбачає використання педагогом сукупності } \\
\text { дослідницьких, пошукових, творчих за своєю суттю методів, прийомів, } \\
\text { засобів...суть проектної технології - стимулювати інтерес студентів до } \\
\text { певних проблем, що передбачають володіння визначеною сумою знань, та } \\
\text { через проектну діяльність, яка включає розв’язання однієї або цілої низки } \\
\text { проблем, показати практичне застосування надбаних знань від теорії до } \\
\text { практики, гармонійно поєднуючи академічні знання } 3 \text { прагматичними, } \\
\text { дотримуючи відповідний їх баланс на кожному етапі навчання }\end{array}$ \\
\hline
\end{tabular}


С. Соболєва $[10$, c. 214$]$ проєктну технологію ми розглядаємо як упорядковану сукупність дій, операцій, процедур та методів (дослідницьких, пошукових, проблемних), навчально-пізнавальних прийомів, що зорієнтовані на застосування фактичних знань для набуття нових, забезпечують досягнення результату (створення проекту) в результаті самостійної роботи студентів, яка діагностується та прогнозується в змінюваних умовах навчального процесу.

Науковцями досліджено основні вимоги до організації проєктної технології [3, с. 86-87], котрі пов'язані зі значущістю в дослідницькому й творчому плані проблеми (завдання) та потребують інтегрованих знань, дослідницького пошуку для iі розв'язання; практичною, теоретичною, пізнавальною значущістю передбачуваних результатів; самостійною (індивідуальною, парною, груповою) діяльністю учнів/студентів; структуруванням змістової частини проекту (з указівкою поетапних результатів); використанням дослідницьких методів: визначення проблеми досліджуваних завдань, висунення гіпотези їхнього розв'язання, обговорення методів дослідження, оформлення кінцевих результатів, аналіз отриманих даних, підбиття підсумків, коректування, висновки.

Основні принципи проєктної технологї представлено [3, с. 87; 10, с. 213]: 1) активністю у виборі завдання та його опрацюванням; 2) життєвим, практичним характером проєкту, його суспільно-корисною установкою; 3) інтересом студентів до роботи; 4) поєднанням теорії з практикою, знаннями, уміннями й навичками; 5) можливістю створювати нові проєкти; 6) спроможністю втілити проєкт; 7) самостійністю; 8) творчістю; 9) колективною діяльністю; 10) принципом людських пріоритетів через підпорядкування процесів проєктування інтересам і можливостям виховання; ненав'язуванням студентам виконання своїх проектів; 11) саморозвитком спроектованих систем, процесів, ситуацій (створенням їх динамічними і гнучкими, готовністю до багаторазового використання в мінливих умовах, варіативністю проектів для досягнення мети); 12) ієрархічністю через здатність до здійснення діяльності на різних рівнях: операційному (виконання окремих технологічних операцій); тактичному (виконання всіх операцій технологічного процесу, орієнтування в змінюваних умовах, планування дій, розподіл ролей); стратегічному (сформованість пізнавальних умінь, творчої активності, умінь зі здійснення самоаналізу процесів та результатів діяльності, широкий кругозір, комунікативність); 13) цілісністю (інтегративністю, потребою самостійного оцінювання ситуації, поповнення знань, визначення мети діяльності, віднайдення ефективних методів і способів дій, опрацювання та вдосконалення, досягнення мети та отримання необхідних результатів).

Більшістю дослідників до головних етапів $i$ практичних дій зі створення педагогічного проєкту віднесено: 1) прогнозування (оформлення інноваційної ідеї проекту через іiі обгрунтування, абстрактне уявлення й опис характеристик майбутнього об’єкта проектування (педагогічної конструкції: технології, методу, змісту освіти, навчальної програми, педагогічної системи, процесу або ситуації), виявлення взаємозв'язку між компонентами об'єкта проектування; ідеальне співвідношення прогнозу з дійсністю; передбачення наслідків перспективних 
змін дійсності, що реалізовуються в педагогічному проекті); 2) моделювання (створення моделі через розроблення та опис цілей, змісту й структурних компонентів моделі об'єкта проектування для забезпечення конкретності, досяжності і гнучкості їнього функціонування; розроблення основних шляхів (умов) досягнення виділених цілей (стан середовища, особливості суб'єктів, функціональні зв'язки між елементами проекту, можливості його ефективного використання, очікувані результати); 3) конструювання (створення конструкту через виготовлення дослідного зразка (синтезування окремих важливих якостей об’єкта в єдине ціле) завдяки актуалізації знань про педагогічний об'єкт і досвід оперування 3 ним на практиці, опис характеристик певного об'єкта, його властивостей, компонентів, виділення нового об’єкта зі збереженням основних ознак оригіналу; деталізація створеного проекту для наближення його до використання в конкретних умовах реальними учасниками та відображення у технологіях, методах, технічних засобах навчання, змісті навчання); 4) відтворення (упровадження проєкту через часткове впровадження, апробацію, уточнення теоретичного проекту (коригування) для провадження подальшого розроблення створеної моделі та доведення іiі до рівня практичного використання; цілісне впровадження, орієнтоване на варіативне масове використання проекту й спрямоване на забезпечення його ефективного функціонування і розвитку). Значущим етапом і практичною дією [3, с. 88-89]; 5) репрезентація і захист проєкту у вигляді наукової доповіді, ділової гри, демонстрації відеофільму, екскурсії, телепередачі, наукової конференції, інсценівки, театралізації, ігри із залом, подорожі, реклами, прес-конференції тощо.

I насамкінець - 6) рефлексія як зіставлення первісних цілей і результатів дослідження, процес глибинного самопізнання суб'єктом своїх внутрішніх психічних станів та актів під час та в результаті виконання проєкту. А також оцінювання (самооцінювання) та підбиття підсумків, розформування команди, обговорення результатів проєкту, яких пізнавальних і моральних якостей набули його учасники.

Науковиями здійснено класифікацію проєктів на види [2;3;8;9]: дослідні (добре продумана структура, визначені цілі, актуальність предмета дослідження для всіх учасників, соціальна значимість, продумані методи (експериментальні, дослідні, обробки результатів), логіка дослідження, структура: аргументація актуальності; визначення проблеми дослідження, предмета, об'єкта, завдань, методів дослідження, джерел інформації, методології дослідження; висування гіпотез; визначення шляхів розв'язання; обговорення отриманих результатів, висновків, оформлення результатів; визначення нових проблем для подальших досліджень); творчі проєкти (відсутність детально опрацьованої структури спільної діяльності учасників, ii розвиток та підпорядкування кінцевому результатові, прийнятій групою логіці спільної діяльності, інтересам учасників проекту, планованим результатам та формі їхнього представлення (газета, твір, відеофільм, драматизація, спортивна гра, свято, експедиція); пригодницькі, ігрові проєкти (відсутня попередня обумовлена структура, відкрита й невизначена 
точно до закінчення проекту; програвання ролей, обумовлених характером i змістом проекту, імітація соціальних або ділових взаємин, ускладнених придуманими учасниками ситуаціями; домінування рольової гри); інформаційні проєкти (збирання інформації про якийсь об’єкт, явище, ознайомлення 3 даними, аналіз і узагальнення фактів; продумана структура, систематичне коригування); практико-орієнтовані проєкти (визначений результат діяльності, орієнтований на соціальні інтереси самих учасників проекту; репрезентація у вигляді документа, створеного за результатами дослідження: 3 екології, біології, географіiі, агрохімії; економіки, фінансів, сфери обслуговування, логістики; історичного, літературознавчого характеру; програми дій, рекомендацій, спрямованих на ліквідацію виявлених невідповідностей у природі, суспільстві тощо).

Відповідно до характеру контактів проєкти поділяються на внутрішні (або регіональні (тобто в межах однісї країни) організують або всередині одного закладу освіти, міждисциплінарні (між закладами освіти всередині регіону, однієї країни) й міжнародні (учасниками є представники різних країн).

За кількістю учасників проєкти бувають особистісні (між двома партнерами в різних закладах освіти, регіонах, країнах); парні (між парами учасників); груповi (між групами учасників).

За комплексністю проєкти можуть бути монопроектами (реалізуються в рамках одного навчального предмета або однієї галузі знання) й міжпредметними (виконуються в позанавчальний час під керуванням фахівців 3 різних галузей знання.).

За тривалістю розрізняють проекти: міні (відбуваються протягом одного навчального заняття або навіть його частини); короткотермінові (тривалістю чотири-шість навчальних занять); тижневі (30-40 годин комбінації аудиторних i позааудиторних форм роботи); довгострокові (річні, як індивідуальні, так i групові) з виконанням у позааудиторний час).

У результаті досліджень з'ясовано, що процес виконання завдань проєкту не обмежується навчальним заняттям, а передбачає тривалу в часі цілеспрямовану діяльність із вирішення низки важливих завдань [6, с. 136]:

- забезпечення взаємозв'язку отриманих теоретичних знань 3 виробленими уміннями й навичками, які в поєднанні з практичними діями здобувачів освіти формують компетентність, впливають на емоційну сферу, забезпечуючи посилення мотивації студентів до вивчення іноземної мови;

- здійснення творчої роботи в межах теми, самостійний пошук необхідної інформації не лише з підручників, а й з інших джерел;

- реалізація різноманітних форм організації навчальної діяльності задля здійснення взаємодії студентів один із одним і з викладачем;

- зорієнтованість освітнього процесу на студента (студентоцентрований підхід) через ураховання його інтересів, життєвого досвіду та індивідуальних можливостей;

- посилення індивідуальної й колективної відповідальності студентів за виконану в межах проєкту роботу, оскільки результати кожного здобувача освіти 
акумулюються в загальному інтелектуальному продукті (працюючи індивідуально чи в мікрогрупі, подає всій групі наслідки своєї діяльності);

- спільна праця в рамках проекту навчає студентів доводити справу до кінця, вони повинні показати результати своєї роботи.

Дослідниками встановлено організаційно-педагогічні умови розроблення проєктних технологій, до яких віднесено цілеспрямовану мотивацію до проєктного професійного навчання; створення сприятливого для проєктного професійного навчання інноваційного освітнього середовища; формування готовності педагогів та здобувачів освіти до проєктної діяльності; підготовку навчально-методичних матеріалів i дидактичних комплексів для проєктного професійного навчання [4, с. 3].

Власний практичний досвід провадження навчально-пізнавальної діяльності в умовах дистанційного навчання, а також викладачів кафедри готельноресторанного та туристичного бізнесу Херсонського державного університету уможливлює здійснення аналітико-синтетичних досліджень щодо особливостей організації вищеозначеного освітнього процесу, зокрема й через використання проєктних технологій.

Значущими в освітньому процесі $є$ фахово орієнтовані дисципліни, які під час дослідження стали системоутворюючою основою формування професійної компетентності фахівців готельно-ресторанної справи: «Технологія продукції ресторанного господарства», «Основи кулінарної майстерності», «Товарознавство та контроль якості продуктів харчування», «Гігієна і санітарія в галузі», «Стандартизація, сертифікація і метрологія», «Міжнародні стандарти якості готельно-ресторанного бізнесу», «Організація ресторанного господарства» тощо. Означені дисципліни навчальних планів унікальні 3 точки зору їхнього змістової наповненості, однак, об'єднуючись особистісно-орієнтованою методологією, забезпечують професійну спрямованість фахової підготовки та спільність аксіологічних детермінант. Навчання здобувачів освіти здійснюється як в очній, так і в дистанційній формах завдяки використанню засобів офлайн i онлайн-комунікацій та цифрових взаємодій: сайтів, блогів, форумів, чатів, діалогів чи листування, конференцій 3 використанням традиційних засобів інтернет-зв'язку: Skype, Facebook, Messenger, Telegram, Viber, YouTube, Googleклас, різноманітних платформ, зокрема Zoom.us, Cisco Webex Meetings, Google Classroom, Moodle, Microsoft Teams, Discord тощо.

Проєктні технології були використані професорсько-викладацьким складом під час реалізації практичної складової освітнього процесу в умовах провадження дуальної форми навчання. Використання матеріально-технічної бази та кадрового складу ресторанів «RUBA HUB», «Терраса», «Моцарт», «Цепелін» та готелів «Оптима Херсон», «Bonita», «Фрегат» (м. Херсон) за сприяння фахівцівпрактиків від виробництва уможливило виконання проєктів на замовлення підприємств - баз практик. Під час викладання дисциплін «Товарознавство та контроль якості продуктів харчування», «Гігієна і санітарія в галузі», «Стандартизація, сертифікація i метрологія» можливості дуальної освіти реалізовуються завдяки тісній співпраці з Держпродспоживслужбою Херсонської 
області, ДП «Херсонстандартметрологія», Херсонською торгово-промисловою палатою та відповідному виконанню проєктів.

Так, під час виконання курсових робіт з навчальної дисципліни «Технологія продукції ресторанного господарства» здобувачі освіти виконували індивідуальні проєкти на заздалегідь визначені й індивідуально узгоджені теми: «Особливості виробництво фаршированих кулінарних виробів на основі рибного фаршу», «Інноваційні технології використання нерибних продуктів моря у приготуванні холодних і гарячих закусок», «Розроблення меню i дослідження технології холодних страв та закусок 3 використанням локальних продуктів Херсонщини для ресторанів», «Удосконалення технології приготування борошняних кондитерських виробів за рахунок використання кукурудзяного борошна», «Особливості технології страв та популяризація кулінарних традицій національної кухні Херсонщини», «Національні традиції Херсонщини у технології страв та виробів із тіста», «Удосконалення технології приготування соусів за рахунок використання фруктових порошків», «Сучасні технології страв iз кавуна - бренда Херсонщини», «Дослідження асортименту, технологій страв i кулінарних виробів у кулінарії Херсонського регіону» тощо.

Аналогічна курсова робота 3 навчальної дисципліни «Основи кулінарної майстерності» передбачала виконання проєктів за темами: «Технологія приготування і оформлення та подавання страв із борошна (вареники, галушки)», «Технології приготування кондитерської продукції», «Технологія приготування страв i кулінарних виробів із яєць та яєчних продуктів», «Технологія приготування солодких страв та компотів із свіжих та швидкозаморожених фруктів та ягід, баштанних Херсонщини», «Технологія приготування страв із продуктів рослинного походження», «Технологія приготування страв із м’яса диких тварин», «Технології страв із десертних овочів Херсонщини», «Технологія приготування українських національних страв 3 круп та бобових», «Технологія приготування охолоджених страв», «Технологія приготування швидко заморожених страв», «Технологія приготування напоїв з використанням гарбуза. Перспективи розвитку асортименту», «Технологія приготування напівфабрикатів та страв 3 риби», «Технологія приготування заливних страв, паштетів», «Технологія приготування напівфабрикатів високого ступеню готовності», «Технологія приготування борошняних кондитерських виробів» тощо.

Наведені вище теми проєктів відповідали вимогам Соціального проєкту «Смаки Херсонщини», започаткованого 3 метою відродження традицій українського кулінарного мистецтва та престижу професій сфери ресторанного господарства Херсонщини за участю провідних керівників закладів ресторанного господарства, шеф-кухарів, барменів. Місія названого проєкту - відродження традицій українського кулінарного мистецтва i престижу професій сфери ресторанного господарства Херсонщини, оновлення вінтажних (старовинних) рецептів області та популяризація регіональних послуг гостинності. Тож науковопедагогічний персонал та здобувачі освіти $є$ активними організаторами й учасниками акцій.

Окрім означеного, викладачі кафедри готельно-ресторанного та 
туристичного бізнесу разом зі студентами науково-проблемної групи «Збереження автентичності кухні Херсонщини та обгрунтування використання локальних інгредієнтів» здійснюють роботу 3 виконання науково-дослідних проєктів щодо розроблення різноманітних кулінарних страв та продукції для закладів ресторанного господарства регіону.

Принагідно зазначимо, що технологія проєктування передбачала розв'язання студентами (групою, командою) заздалегідь визначеної можливої (імовірної) професійної проблеми з використанням різноманітних методів, засобів навчання та інтегрування знань, умінь 3 фахово орієнтованих та інших дисциплін освітньопрофесійної (освітньо-наукової) програми підготовки фахівців освітніх рівнів «бакалавр» і «магістр» спеціальності 241 Готельно-ресторанна справа, їхньої індивідуальної ініціативності та творчості.

Упровадження проєктної технології передбачало індивідуальну, групову (парну та мікрогрупову) i колективну діяльність здобувачів освіти, а отже, різноманітну взаємодію (колаборацію).

Виконання індивідуального завдання в рамках групової роботи над проєктами стимулювало здобувачів освіти до пошуку нестандартних шляхів вирішення поставленого завдання, спонукало до самоосвіти, оскільки від їхнього особистого внеску в загальний проєкт залежив успіх всієї команди і ставлення членів команди до нього. Групова робота сприяла формуванню в майбутніх фахівців готельно-ресторанної справи толерантності, емпатії, рефлексіїі, колаборативності.

У процесі реалізації проєктної технології перед здобувачами освіти ставилися завдання:

1) узагальнити знання щодо сутності методу проєктів і специфіки його застосування;

2) розробити ідеї для реалізації проєкту під час вивчення конкретних тем із дисциплін освітньо-професійних, освітньо-наукових програм;

3) підібрати інформаційний матеріал;

4) використовувати у процесі проєкту програмне забезпечення та сервіси (Microsoft Power Point, Wizer.me, Triventy тощо);

5) оформити проєкт та репрезентувати його;

6) реалізувати проєкт у практичній діяльності на підприємствах готельноресторанного бізнесу регіону.

У процесі підготовки проєкту здобувачі освіти готували навчальнометодичні матеріали, які містили:

1) мету, завдання та план проекту з урахуванням державних стандартів та навчальних програм дисциплін;

2) методичні матеріали (пам'ятки 3 вимогами до здійснення проєктів, організації роботи з його виконання, перелік інформаційних джерел);

3) матеріали проекту у вигляді мультимедійної презентації, відеорепортажу, буклета, квесту, кулінарної страви, продукції тощо).

Проєкти, інтегровані у традиційний освітній процес підготовки фахівців освітніх рівнів «бакалавр» і «магістр» спеціальності 241 Готельно-ресторанна 
справа, передбачали виконання творчих та дослідницьких завдань у рамках навчального курсу. Найбільш типовим стало використання міні-проєктів як одного із завдань аудиторного заняття або заключного завдання заняття. У проєктах цього типу виконувалися творчі завдання 3 індивідуальною чи груповою репрезентацією кулінарної страви або продукції.

Висновки. Узагальнюючи викладене, підкреслимо, що проєктна технологія розвиває у здобувачів освіти ініціативу, самостійність, організаторські здібності, стимулює процес саморозвитку. Ії активне використання в закладах вищої освіти забезпечує професійну компетентність, формує творчу особистість, удосконалює розумові здібності, пізнавальні вміння, дає можливість брати участь в ефективній майбутній фаховій діяльності, реалізації в професії та концепції власного життєвого успіху.

\section{Лimepamypa:}

1. Сілакова Т. Т. Проектні технології підготовки студентів. Вісник Національного авіаційного університету. Педагогіка та психологія. 2017. № 11. С. 153-158.

2. Науменко Н. В., Козлов А. В. Можливості проєктної технології навчання у професійній підготовці майбутніх фахівців. Current trends and factors of the development of pedagogical and psychological sciences in Ukraine and EU countries : International scientific and practical conference (Lublin, September 25-26, 2020). Lublin, 2020. P. 157-160.

3. Колодницька О. Проектні технології в процесі професійно-педагогічної підготовки майбутніх фахівців закладів вищої освіти. Психолого-педагогічні проблеми сільської школи. 2018. Вип. 59. С. 84-91.

4. Кулалаєва Н. В., Романова Г. М. Проектні технології для професійної підготовки майбутніх кваліфікованих робітників аграрної, будівельної та автотранспортної галузей. Вісник НАПН Украӥни. 2019. № 1(1). С. 1-6.

5. Мелько М. Проектні технології у процесі професійної підготовки майбутніх кухарівкондитерів. URL: https://lib.iitta.gov.ua/706644/2/Melko\%20stat..pdf

6. Поночовна-Рисак Т. М., Величко I. Г. Проектна методика навчання професійного спілкування в процесі вивчення іноземних мов майбутніми фахівцями готельно-ресторанної справи. Інноваційна педагогіка. 2019. Вип. 11. Т. 2. С. 134-137.

7. Тимейчук А. М. Підготовка майбутніх магістрів 3 туризмознавства до проектної професійної діяльності : дис....канд. пед. наук. Вінниця, 2018. 263 с.

8. Протас О. Проєктні технології у процесі підготовки майбутніх соціальних педагогів до роботи з обдарованими дітьми. Наукові записки Тернопільського національного педагогічного університету імені Володимира Гнатюка. Серія: педагогіка. 2020. № 1. URL: http://nzp.tnpu.edu.ua/article/view/205912

9. Розумна Т.С. Активізація пізнавальної діяльності студентів засобами проектної технології на заняттях з іноземної мови у ВНЗ. Вісник Дніпропетровського університету імені Альфреда Нобеля. Серія «Педагогіка і психологія». 2015 . № 2 (10). С. 275-279.

10. Соболєва С. М. Проектні технології та їх роль у процесі практично-професійної підготовки студентів економічних спеціальностей. Наукові записки кафедри педагогіки. 2012. Вип. XXVIII. С. 210-215.

11. Теорія і практика проектного навчання у професійно-технічних навчальних закладах: монографія / В. М. Аніщенко та ін.; за заг. ред. Н. В. Кулалаєвої. Житомир: «Полісся», 2019. 208 c.

12. Бурак В. Г. Модернізація професійної підготовки фахівців готельно-ресторанного господарства. Нова педагогічна думка. 2020. № 4 (104). С. 7-12.

13. Бурак В.Г. Концептуальні основи професійної підготовки майбутніх фахівців 
готельно-ресторанної справи в закладах вищої освіти. Актуальні питання гуманітарних наук. 2021. № 37. C. 202-209.

14. Бурак В.Г. Специфіка формування компетентності фахівців готельно-ресторанної справи в процесі професійної підготовки в закладах вищої освіти. Нова педагогічна думка. 2021. №2 (106). С. 32-38.

15. Бурак В. Г. Професійна підготовка майбутніх фахівців готельно-ресторанної справи в контексті реформи освіти та науки. Вісник Польсько-української науково-дослідної лабораторії дидактики імені Я. А. Коменського. Вип. 2(22): Сучасні проблеми обдарованості особистості: II Міжнар. наук.-практ. конф. (Умань, 20-21 травня 2021). Умань, 2021. С. 28-32.

16. Бурак В. Г. Смарт-технології в професійній підготовці майбутніх фахівців готельноресторанної справи. Сучасні напрями розвитку педагогіки та педагогічної психологї̈; актуальні питання філології та мовознавства: II Міжнар. спеціаліз. наук. конф. (ІваноФранківськ, 11 червня 2021). Івано-Франківськ, 2021. С. 83-86.

17. Бурак В.Г. Імерсивні технології в професійній підготовці майбутніх фахівців готельно-ресторанної справи. Priority directions of science and technology development: матеріали XI Міжнар. наук.-практ. конф. (Київ, 11-13 липня 2021). Київ, 2021. С. 322-326.

\section{References:}

1. Silakova, T. T. (2017). Proektni tekhnolohii pidhotovky studentiv. Visnyk Natsionalnoho aviatsiinoho universytetu [Project technologies for students training]. Pedahohika ta psykholohiia, 11, 153-158 [in Ukrainian].

2. Naumenko, N. V., \& Kozlov, A. V. (2020). Mozhlyvosti proiektnoi tekhnolohii navchannia u profesiinii pidhotovtsi maibutnikh fakhivtsiv [Possibilities of project technology of training in professional training of future specialists]. Proceedings from International scientific and practical conference «Current trends and factors of the development of pedagogical and psychological sciences in Ukraine and EU countries» (pp. 157-160). Lublin [in Ukrainian].

3. Kolodnytska, O. (2018). Proektni tekhnolohii v protsesi profesiino-pedahohichnoi pidhotovky maibutnikh fakhivtsiv zakladiv vyshchoi osvity [Project technologies in the process of professional and pedagogical training of future specialists in higher education institutions]. Psykholohopedahohichni problemy silskoi shkoly, 59, 84-91. [in Ukrainian].

4. Kulalaieva, N. V., \& Romanova, H. M. (2019). Proektni tekhnolohii dlia profesiinoi pidhotovky maibutnikh kvalifikovanykh robitnykiv ahrarnoi, budivelnoi ta avtotransportnoi haluzei [Project technologies for professional training of future qualified workers in the agricultural, construction and motor transport industries]. Visnyk NAPN Ukrainy, 1(1), 1-6. [in Ukrainian].

5. Melko, M. Proektni tekhnolohii u protsesi profesiinoi pidhotovky maibutnikh kukharivkondyteriv [Project technologies in the process of professional training. future pastry chefs]. Retrieved from https://lib.iitta.gov.ua/706644/2/Melko\%20stat..pdf [in Ukrainian].

6. Ponochovna-Rysak, T. M., \& Velychko, I. H. (2019). Proektna metodyka navchannia profesiinoho spilkuvannia $\mathrm{v}$ protsesi vyvchennia inozemnykh mov maibutnimy fakhivtsiamy hotelnorestorannoi spravy [Project methods of teaching professional communication in the process of learning foreign languages by future specialists in hotel and restaurant business]. Innovatsiina pedahohika, 11 (2), 134-137 [in Ukrainian].

7. Tymeichuk, A. M. (2018). Pidhotovka maibutnikh mahistriv z turyzmoznavstva do proektnoi profesiinoi diialnosti [Preparation of the future masters of tourism studies for the project professional activity]. Candidate's thesis. Vinnytsia: VDPU [in Ukrainian].

8. Protas, O. (2020). Proiektni tekhnolohii u protsesi pidhotovky maibutnikh sotsialnykh pedahohiv do roboty z obdarovanymy ditmy [Project technologies in the process of preparing future social teachers for work with gifted children]. Naukovi zapysky Ternopilskoho natsionalnoho pedahohichnoho universytetu imeni Volodymyra Hnatiuka. Seriia: pedahohika, 1. Retrieved from http://nzp.tnpu.edu.ua/article/view/205912 [in Ukrainian]. 
9. Rozumna, T. S. (2015). Aktyvizatsiia piznavalnoi diialnosti studentiv zasobamy proektnoi tekhnolohii na zaniattiakh z inozemnoi movy u VNZ [Activation of cognitive activity of students by means of project technology at the lessons of foreign language at the university]. Visnyk Dnipropetrovskoho universytetu imeni Alfreda Nobelia. Seriia «Pedahohika i psykholohiia», 2 (10), 275-279 [in Ukrainian].

10. Sobolieva, S. M. (2012). Proektni tekhnolohii ta yikh rol u protsesi praktychno-profesiinoi pidhotovky studentiv ekonomichnykh spetsialnostei [Projective technologies and their role in the process of practical - professional training students of economics]. Naukovi zapysky kafedry pedahohiky. Vyp. KhKhVII, 210-215 [in Ukrainian].

11. Anishchenko V. M. (Eds.). Teoriia i praktyka proektnoho navchannia u profesiinotekhnichnykh navchalnykh zakladakh (2019). [Theory and practice of project-based learning in vocational schools]. Zhytomyr: «Polissia» [in Ukrainian].

12. Burak, V. H. (2020). Modernizatsiia profesiinoi pidhotovky fakhivtsiv hotelno-restorannoho hospodarstva [Modernization of professional training of hotel and restaurant specialists]. Nova pedahohichna dumka, 4 (104), 7-12. [in Ukrainian].

13. Burak, V. H. (2021). Kontseptualni osnovy profesiinoi pidhotovky maibutnikh fakhivtsiv hotelno-restorannoi spravy $\mathrm{v}$ zakladakh vyshchoi osvity [Conceptual framework of professional training of future specialists in hotel and restaurant business in higher education institutions]. Aktualni pytannia humanitarnykh nauk, 37, 202-209 [in Ukrainian].

14. Burak, V. H. (2021). Spetsyfika formuvannia kompetentnosti fakhivtsiv hotelno-restorannoi spravy $\mathrm{v}$ protsesi profesiinoi pidhotovky $\mathrm{v}$ zakladakh vyshchoi osvity [Specifics of competence formation of future specialists in hotel and restaurant business in the process of professional training in higher educational establishments]. Nova pedahohichna dumka, 2 (106), 32-38 [in Ukrainian].

15. Burak, V. H. (2021). Profesiina pidhotovka maibutnikh fakhivtsiv hotelno-restorannoi spravy v konteksti reformy osvity ta nauky [Professional training of future professionals of hotel and restaurant business in the context of educational and scientific reform]. Visnyk Polsko-ukrainskoi naukovo-doslidnoi laboratorii dydaktyky imeni Ya. A. Komenskoho. Vyp. 2(22): Proceedings from II Mizhnarodna naukovo-praktychna konferentsiia «Suchasni problemy obdarovanosti osobystosti» (pp. 28-32), Uman [in Ukrainian].

16. Burak, V. H. (2021). Smart-tekhnolohii v profesiinii pidhotovtsi maibutnikh fakhivtsiv hotelno-restorannoi spravy [Smart technologies in the training of future specialist in hotel and restaurant business]. Proceedings from II Mizhnarodna naukovo-praktychna konferentsiia «Suchasni napriamy rozvytku pedahohiky ta pedahohichnoi psykholohii; aktualni pytannia filolohii ta movoznavstva» (pp. 83-86). Ivano-Frankivsk [in Ukrainian].

17. Burak, V. H. (2021). Imersyvni tekhnolohii v profesiinii pidhotovtsi maibutnikh fakhivtsiv hotelno-restorannoi spravy [Immersive technologies in the professional training of future specialists in hotel and restaurant business]. Proceedings from XI Mizhnarodna naukovo-praktychna konferentsiia «Priority directions of science and technology development» (pp. 322-326). Kyiv [in Ukrainian]. 